\title{
Contemporary Chinese Calligraphy Between Tradition and Innovation
}

\author{
Adriana Iezzi \\ Sapienza University of Rome, Rome, Italy
}

\begin{abstract}
Since the mid-1980s Chinese calligraphy art has undergone a radical change and has opened itself to experimentation. A vivid debate on CCC (Contemporary Chinese Calligraphy) (Zhongguo xiandai shufa) is involving art critics in China nowadays. WANG Dongling and the modernists think that, despite many changes and influences, we can still refer to the traditional calligraphic lexicon to describe the calligraphic production of contemporary Chinese art. They still remain deeply rooted in the signified system of Chinese writing, even if they break with the strict rules of Chinese classical aesthetic (contamination of Western elements and focus on the stylistic exploration). WANG Nanming and the Avant-garde think that "contemporary calligraphy is not calligraphy yet": It is "anti-calligraphy", annihilates Chinese tradition, rejects the use of legible characters, experiments with new languages and new media within the idiom of international contemporary art. The result is the creation of works of art that could be assimilated to Abstract art, Abstract expressionism, Conceptual art, Performance art, Contemporary dance, Multimedia art, and even Street art. This paper aims at showing how still valid and extremely productive are both these two theoretical and creative/practical approaches to Chinese calligraphy in China nowadays. They turned the art of calligraphy into a medium for global comprehension and communication.
\end{abstract}

Keywords: CCC (Contemporary Chinese Calligraphy), modernism, Avant-garde, WANG Dongling, WANG Nanming

\section{Introduction}

The art of Chinese calligraphy is much more than the art of producing beautiful writing decoratively arranged to embellish surface. It represents one of the most important art form that has been practice in China until now, and it is unique in a perspective of world art, because its particular features cannot be found in European or Islamic writing. Chinese calligraphy is the only major art form in the world that allows the viewer to retrace the creation on a finished work in all its consecutive phases, following with his eye the exact movements of the brush and feeling the rhythm in the writer's hand. It allows the viewer to experiment the factor of time on the sensation of movement and to feel intimacy with the writer itself. It also represents a medium in which the personality of the writer is revealed, and it is valued as an immediate expression of the individuality of the calligrapher. Through the sheer calligraphic vitality of the brush, the artist expresses not only his inner world, but also his awareness of the life of things in the world.

Adriana Iezzi, Ph.D. candidate, Department of Oriental Studies, Sapienza University of Rome. 
The shapes of world images and of its powerful forces are embodied in the brushstrokes of calligraphic artworks. In this perspective, "calligraphy" (shufa) not only represents "the art and the discipline of writing", but also reveals the "written paradigm" ("written" shu + "paradigm" fa) of the cosmic patterns. It becomes a means of representation of the universal dynamism, that is of the world energy ( $q i$ ) ordered by the universal principle (li), as well as, an energetic extension of the human body in its psychophysical unity (xin) and of the cosmic substance $^{1}$. The original meaning of the word "calligraphy" clearly discloses this assumption: The word "calligraphy" (shufa) is indeed composed of the character shu that means "writing", "written text", and of the term fa that means "law", "method", and "way", but whose translation also connotes aspects of the terms "paradigm", "model", "pattern", "figure", and "image"2. In addition to be considered as an aesthetic presentation of the Chinese script styles, as a representation of things and ideas by graphic means, and as an artistic vehicle of self-expression, a reflection of calligrapher's inner being or the extension of the movement of their body ${ }^{3}$, Chinese calligraphy is also be treated as the "embodied image" of the universal macrocosm.

Furthermore, throughout the centuries, calligraphy was not only a means of written communication, as it is in any language, but also a political instrument of social control as well as it was an instrument of social cohesion among the political and cultural elite of Chinese literati ${ }^{4}$. The art of calligraphy was intimately connected with the art of poetry and with the art of painting, and it was one of the so-called "Three perfections" (san jue), that are indeed poetry (shi), calligraphy (shu) and painting $(h u a)^{5}$. These were the three forms of art that every educated official was expected to master in the China's Empire and they usually were simultaneously used to shape a single work of art. Because of its strict connection with the literary tradition and the classical writings, calligraphy helped to contribute to the extraordinary cohesiveness of the Chinese artistic and cultural tradition. From the fourth century onwards, classical models were canonized, the calligraphic techniques did not changed any more, and the stability of aesthetic and stylistic standards ensured that the continuity principle of cultural identity remains intact.

\section{The Birth of Chinese Contemporary Calligraphy}

From the end of the 19th century, especially after the collapse of the Chinese Empire (1911) and with the advent of Communism (1949), the impressive stability and cohesiveness of the art of calligraphy began to fade. After MAO Zedong's death in 1976 and the so-called "Four Modernizations" brought about by DENG Xiaoping in 1978, a process of "modernization" started in different fields of society, a process that has opened China to the

\footnotetext{
${ }^{1}$ For futher information about the relationship among the Chinese concepts of $q i$, li, and xin in the context of Chinese calligraphy aesthetics, see Pasqualotto, G. (2007), Figures of Thought: Works and Symbols in the Oriental Cultures (Figure di pensiero. Opere e simboli nelle culture d'Oriente) (pp. 105-127).

2 For more details on this ethimological interpretation, see LIU, C. Y. (2000), "Embodying Cosmic Patterns: Foundation of an Art of Calligraphy in China" (pp. 2-9). In this article, LIU explained that "The close relationship between brushstroke, character, and text, forms an integral continuum in the creation of writing $(s h u)$, and the operative link between them is fa-brush method (bifa), written paradigm (shufa), and literary rules (wenfa)" (p. 2).

${ }^{3}$ For these different approaches on calligraphy, see the articles included in the exhibition catalogue SHEN, C. Y. F. (1977), Traces of the Brush. Studies in Chinese Calligraphy.

${ }^{4}$ See Ledderose, L. (1986), "Chinese Calligraphy: Its Aesthetic Dimension and Social Function" (pp. 35-50). The political and social function of calligraphy highlighted by Lothar Ledderose is not only a characteristic feature of Chinese ancient tradition, but it is also evident in modern times. See Kraus, R. C. (1991), Brushes with Power: Modern Politics and the Chinese Art of Calligraphy.

${ }^{5}$ For more details about the relationship among poetry, painting, and calligraphy in Chinese art, see Sullivan, M. (1980), The Three Perfections: Chinese Painting, Poetry and Calligraphy.
} 
rest of the world. As to art, in 1979 the first Chinese Avant-garde artistic movement, called the "Stars group", came into being. Calligraphy became so popular that in 1981 a CCA (Chinese Calligraphers' Association) (Zhongguo shufajia xiehui), founded by the government itself, gathered thousand of calligraphers. The artistic atmosphere was very fervent and brought to the First Exhibition of Chinese Modern Calligraphy (Zhongguo xiandai shufa shouzhan), which represented the birth of CCC (Contemporary Chinese Calligraphy) (Zhongguo xiandai shufa) and of the modernist movement. The exhibition was held in October 1985 at the National Art Museum of China in Beijing. The artworks displayed in the exhibition were 72 and all of the artists involved in the exhibition were members of the "Chinese Modern Painting and Calligraphy Association" (Zhongguo xiandai shuhua хиеhui). This association was founded in July 1985 and its major task was to successfully organize this pivotal event. The most important calligraphers who took part in the exhibition were HUANG Miaozi (1913-2012), ZHANG Ding (1917-2010), and LI Luogong (1917-1982), who belong to the old generation of Chinese calligraphy masters, together with GU Gan (b. 1942), WANG Xuezhong (b. 1925), MA Chengxiang (b. 1937), and DAI Shanqing (1944-2004), who were the promoters of the exhibition ${ }^{7}$. Their works were neither calligraphies nor paintings but they were something that participated both in calligraphy practice and painting conceptions $^{8}$. The ideas of "Expressionist calligraphy" and "Abstract art" were linked in the increasingly pictographic shape of the characters, and in the abstract combination of dots and lines. The reinterpretation of the traditional ideas of painting and calligraphy, the influence of contemporary Japanese calligraphy, the use of new materials, and the emergence of new visions, leaded to new results in the artistic field as a reaction to the feelings of the time and to changes in Chinese society. The most representative picture of the exhibition is entitled The Mountains are Breaking up (Shan cui, see Figure 1) and its author is GU Gan, the coordinator of the exhibition and of the modernist movement. The title of the picture reflects the spirit of the time: The word "breaking" (cui) clearly suggests how calligraphy was symbolically rejecting old ideas and representing the birth of new ones.

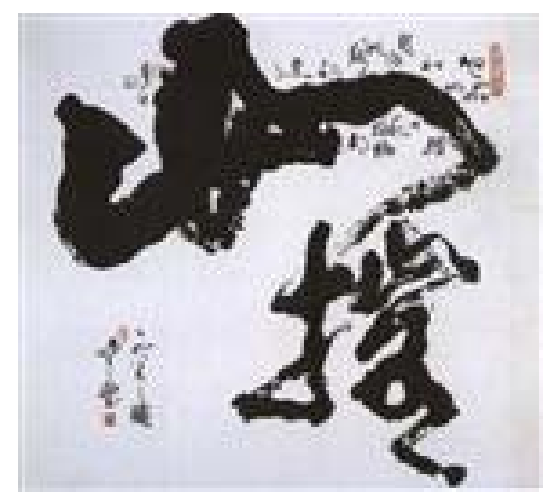

Figure 1. GU Gan, The Mountains Are Breaking Up (Shan cui 山摧) (1985), ink on paper,

$93.5 \mathrm{~cm}$ x $87.5 \mathrm{~cm}$, London, British Museum. Reproduced in Barrass (2002, p. 55).

\footnotetext{
${ }^{6}$ For more details about the birth and the evolution of the "Stars group" (Xingxing 星星), see HUANG, R. (Ed.), (2007), Huang Rui: The Stars' Times, 1979-1984.

${ }^{7}$ For a detailed reconstruction of the exhibition planning process and of the different phases of the exhibition, see PU, L. P. \& GUO, Y. P. (2005), A Survey History from Chinese Contemporary Calligraphy to the Art of Chinese Characters (Zhongguo xiandai shufa dao hanzi yishu jianshi 中国现代书法到汉字艺术简史) (pp. 19-24).

${ }^{8}$ The artworks displayed in the exhibition are gathered in the exhibition catalogue: WANG, X. Z. (Ed.), (1986), A selection of works from the First Session of Chinese Modern Painting and Calligraphy Association (Xiandai shuhua xuehui shufa shoujie zuopin xuan 现代书画学会书法首届作品选).
} 
Even before the Modernist movement had fully gathered momentum, the first shoots of the Avant-garde movement were beginning to sprout. The forerunner of the movement was the calligrapher BAI Qianshen (b. 1955): In 1981, he was the first to write eight formal Chinese "characters" which were in fact wholly unreadable, because they were arbitrarily composed of section of different characters. In 1983, GU Wenda (b. 1955) craved his first "Fake Characters Seal" with two seemingly authentic Chinese characters wholly unreadable yet. This was the starting point for the artist's experimentation and the beginning of his reflection upon Chinese calligraphy and language that aimed to a complete deconstruction of both of them. The results of his attempt were embodied in three important works: (1) The Mythos of Lost Dynasties (Yishi de wangchao, 1983-1987), a series of big panels where he wrote meaningless and unreadable characters, based on the seal scripts; (2) Pseudo-Characters Series (Xugou wenzi xilie, 1984-1986, see Figure 2), a series of ink paintings in which he used traditional calligraphic styles and techniques but subverted them with reversed, upside down or incorrect letters; (3) Speechless \#1-2 (Wu yan \#1-2, 1985), one of the first pieces of Performance art in China, which was held at the Hangzhou Academy of Art, pronouncing meaningless words in front of gigantic characters painted by the author, and completely invented ${ }^{9}$.

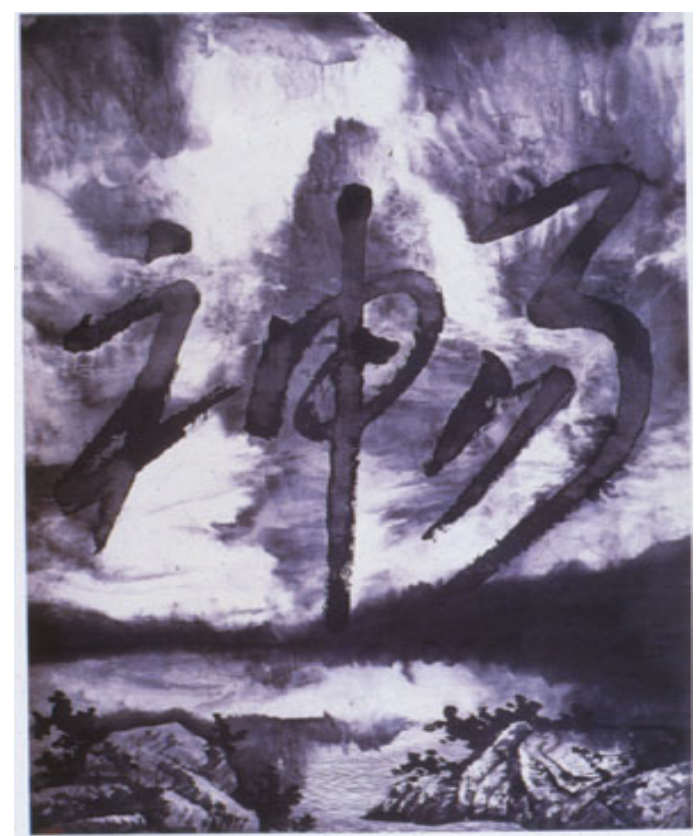

Figure 2. GU Wenda, Pseudo-Characters Series: Contemplation of the World (1984) (detail), ink on paper, $247.3 \mathrm{~cm}$ x $182.9 \mathrm{~cm}$, collection of ZHEN Guo. Source: Bessire (2003, p. 198).

But was only in 1988 that the Avant-garde movement had its top with the works of three other important artists:

(1) Red Humor (Hongse youmo, 1986-1987, see Figure 3) by WU Shanzhuan (b. 1960): It consists of a chamber whose walls are covered with Cultural Revolution slogans freely mixed with advertising pitches, and ancient poems; on the floor four large characters say, "Nobody knows what it means". Combining and juxtaposing meaningless sentences of the mass cultural language, he "creates a kind of non-sensical or

\footnotetext{
${ }^{9}$ For more details on these three works and others GU Wenda's works related to calligraphy, see Chiu M. (2002), "The Crisis of Calligraphy and the New Way of Tea: An Interview with Wenda Gu" (pp. 100-104).
} 
multi-sensed text, by which he eliminated the illusion of any authorship" (M. L. GAO, 2000, p. 169).

(2) Book from the Sky (Tian Shu, 1987-1991, see Figure 4) by XU Bing (b. 1955): It consists of a huge installation composed by the papers of a book printed with more than 4,000 thousand characters completely meaningless, even if they look like Chinese characters. It represents a dramatic celebration of the universal nonsense, and a powerful negation of Chinese history, culture, literature, and language ${ }^{10}$.

(3) The third work is entitled The First Four Series (Zuichu de si ge xilie, 1988-1989) ${ }^{11}$ by QIU Zhenzhong (b. 1947). It was composed of four different series: "New Poems", "Word Series", "Signatures", and "Characters to Be Deciphered" (see Figure 5). For this last series, he took inspiration from characters carved on the pre-Qin Dynasty (pre-221 B.C.) coins to write beautiful lines on paper, even if those characters have not been interpreted yet in their linguistic meaning.

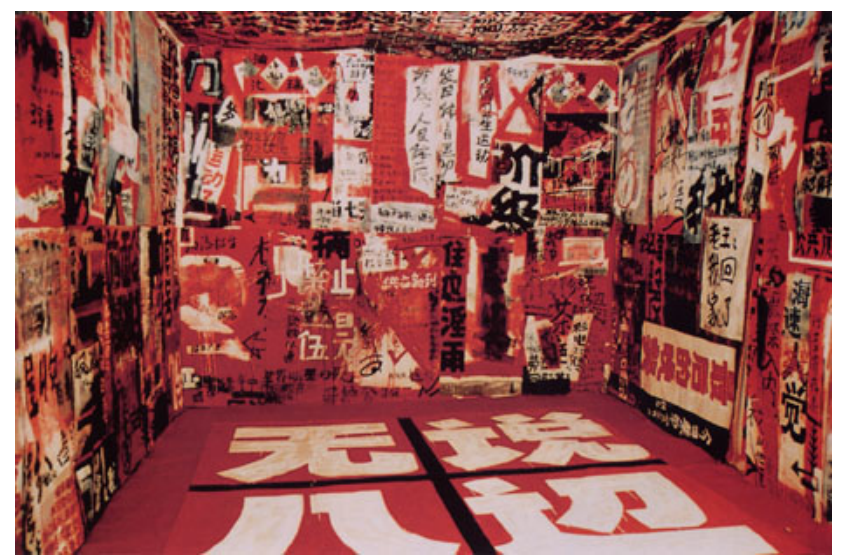

Figure 3. WU Shanzhuan, Red Humor (1986) (installed in Hangzhou, 1986), installation with works on paper, dimensions variable, collection of the artist. Source: M. L. GAO (1998, p. 85).

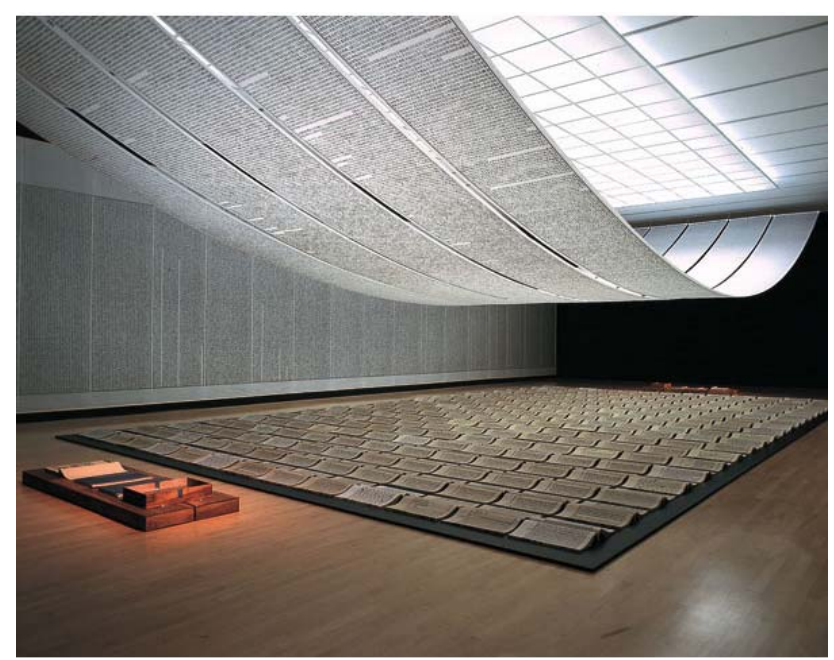

Figure 4. XU Bing, Book from the Sky (1987-1991) (installed at the North Dakota Museum of Art, 1992), installation with hand-printed books, dimensions variable, collection of the artist. Source: M. L. GAO (1998, p. 87).

\footnotetext{
${ }^{10}$ For a detailed analysis of this work and others XU Bing's works related to calligraphy, see Erickson, B. (2001), Words without Meaning, Meaning without Words: The Art of Xu Bing.

${ }^{11}$ For a detailed analysis of this series, see QIU, Z. Z. (1989), The First Four Series (Guanyu zuichu de si ge xilie ji qita 关于最 初的四个系列及其他) (pp. 26-29).
} 


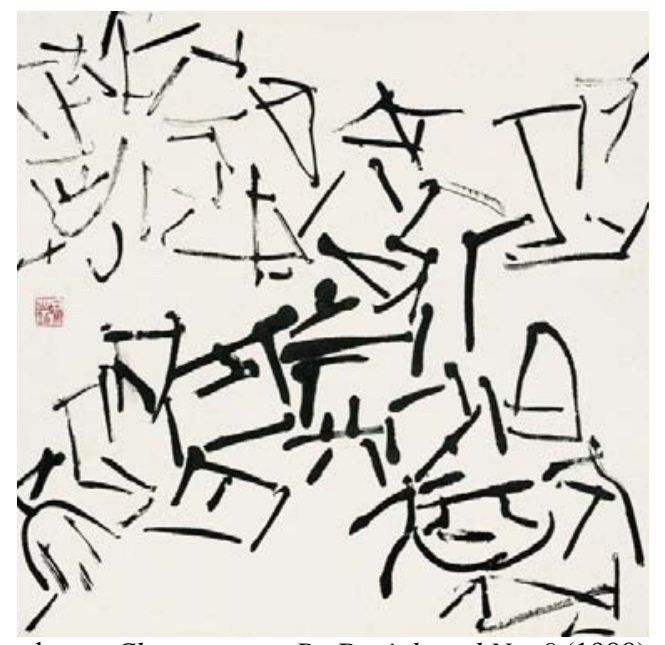

Figure 5. QIU Zhenzhong, Characters to Be Deciphered No. 9 (1988), ink on xuan paper, $68 \mathrm{~cm}$ x $68 \mathrm{~cm}$, collection of the artist. Source: Z. Z. QIU (1989, p. 28).

\section{The Four Currents of CCC}

From this moment onwards, as Barrass (2002) pointed out, four distinct trends became evident in the evolution of the art of calligraphy:

Initially, by far the most influential of these was the continuation of the "Grand Tradition" of Classical calligraphy. Then, in the middle 1980s, a Modernist movement emerged that created an entirely new genre of the art. Later, the decline in the number of truly Classical calligraphers was offset by the rise of many younger Neo-classicists, who keep the Classical idea alive by setting them within a modern context. More recently still, an Avant-garde movement has come to the fore, exploring new artistic possibilities by combining calligraphic imagery and techniques with modern forms of conceptual and Performance art. (p. 11)

According to Barrass (2002), four are the currents of CCC. The currents are Classicism, Neoclassicism, Modernism, and Avant-garde. The last two ones are particularly important for the evolution of calligraphic art, because they are based on experimentation which has brought to a radical change in the field, under the influence of Japanese contemporary calligraphy and Western art. While Classicism and Neoclassicism still reflect the traditional idea of calligraphy, Modernism and Avant-garde have modified the traditional concept of calligraphy completely, so the analysis of these last two currents becomes of the utmost importance.

\section{The Modernist and the Avant-Garde Movements ${ }^{12}$}

Because since the mid-1980s calligraphy has undergone a radical change and has gradually lost its connection with Chinese language and with the traditional concepts of calligraphic art, a vivid debate on CCC is involving art critics in China nowadays (J. S. FU, 1998, 2011; Y. G. ZHANG, 1998; Q. S. ZHU, 2004; T. M. GAO, 2004; Z. Z. QIU, 2004; D. Z. CHEN, 2005; Z. C. LIU, 2006; M. X. CHENG, 2006; A. G. ZHANG, 2008; C. M. LIU, 2010). Professor WANG Dongling (b. 1945) is the main representative of the modernists' point of view, while Professor WANG Nanming (b. 1962) belongs to the Avant-garde. The two have contrastive opinions on CCC, because WANG Dongling (2005, 2011, pp. 6-11) sustained that CCC was still calligraphy, while WANG Nanming (1994, 2005, pp. 12-14) sustained that CCC was not calligraphy yet.

\footnotetext{
${ }^{12}$ In this section, Chinese-English translations are by the author (see WANG Dongling, 2005; WANG Nanming, 2005).
} 


\section{The Modernist Movement}

In the details, WANG Dongling (2005) wrote that "contemporary calligraphy is still calligraphy" (p. 10), characterized by two main elements: firstly, the aesthetic flavour and the spiritual value or content of the traditional calligraphy; and secondly, the concepts of contemporary art (D. L. WANG, p. 6). Using the words of WANG Dongling (2005), this means that, "Contemporary creative action needs the support and the comparison with the tradition" (p. 7), because "it is from traditional calligraphy that contemporary calligraphy was arisen" (p. 10). But modernism, as intended by WANG Dongling, also includes the characteristics, the quality, and the substance of contemporary art, especially Abstract art. WANG Dongling argues that a new interpretation of the concept of Abstract art is still existing in the concept of traditional calligraphy. As early as the first century A.D., Eastern people had already revealed the power of abstraction in calligraphy and ink painting. During the Eastern Han dynasty (25-220 A.D.), when the famous Chinese scholar CAI Yong (132-192) talked about calligraphy with other eminent literati, he first used the metaphor of "abstract lines" to describe calligraphic lines. This idea of "abstract calligraphy" gradually settled in the Chinese people's minds and became a distinctive feature of Chinese aesthetic perception. Since then, sensitivity towards abstract forms of art became much deeper in Chinese people than in Western people, and, as a consequence, as WANG Dongling $(2005$, p. 8) aptly observed: Eastern people have recently come into contact with Western Abstract art and this contact has (re)awakened the aesthetic power of Chinese abstract line.

As a whole, CCC also reflects a deep influence of the new artistic Chinese waves (Zhongguo xiandai yishu xinchao), especially of the ' 85 New Wave Art Movement (Bawu xinchao), as well as the influence of Japanese calligraphy Avant-garde (Riben de qianwei shufa/Riben xiandai shufa) and European and American art (Ou-Mei xiandai yishu/Nalaizhuyi) (D. L. WANG, 2005, p. 10; L. F. QU, 2008, p. 108). This is why WANG Dongling (2005, p. 11) wrote: Even if calligraphy is a very ancient and traditional art, in its modern use it is expression of contemporary reality both in the form and in the content.

Thanks to his own experience as contemporary artist and calligrapher who travelled around the world and lived abroad for many years (he lived in the USA from 1989 to 1992, and in Japan from 1993 to 1994), he became conscious of the fact that in addition to being a free-spirited, independent thinker with a strong personality who possesses creativity and artistic sensitivity, a contemporary Chinese calligrapher must also have great knowledge of Chinese classical culture and have assiduously practiced the traditional arts. Moreover, besides these basic requirements, a contemporary Chinese calligrapher should have a modern way of thinking, and he should pay attention to real life and cultural trends. He should be interested in Western culture, and he should absorb the best of Western tradition. Although well-versed in every field of learning, his first purpose should be to establish a solid alliance between Chinese and Western art. At the end of his article, WANG Dongling (2005) explained that:

To be a "contemporary calligrapher" you firstly need to be a "contemporary artist". [...] To be a "contemporary artist" you need to absorb the best of human culture. Only by doing so can you enrich yourself and develop your own. (p. 11)

In conclusion, Professor WANG Dongling sustains that contemporariness of an art not always means the subversion of the tradition: He thinks that this is a narrow-minded way of thinking that ignores the pluralism of people's contemporary life and the richness of people's spiritual needs. He stresses the point that the 
contemporariness of calligraphy finds expression in two aspects: The first, the fine taste and the spiritual value of the tradition is the source of restructuring a spiritual homeland in the contemporary time, and the eternity of calligraphy aesthetics can fill the spiritual hollowness cause by aesthetic fatigue. The second, the contemporary art concepts can be used to deconstruct and reorganize the artistic and humanistic value of the traditional calligraphy, thus providing cultural genes in the construction of the contemporary art and cultural philosophy. As WANG Dongling demonstrates, supported by other art critics (Barrass, 2002; Y. ZHANG, 2005, pp. 20-21; C. H. HU, 2005, pp. 22-25; Y. S. YANG, 2009, pp. 201-233), in the theoretical reflection of the Modernist movement, tradition and contemporary features are well-balanced and completely intermingled.

This is true not only in the theoretical field but also in the practical approach and in the creative work of the modernist calligraphers. In fact, they still remain deeply rooted in the signified system of Chinese writing, even if they break with the strict rules of Chinese classical aesthetics, focusing on the stylistic exploration. In their works, they reduce the number of characters drastically and reshape them creatively, especially because they are influenced by the Japanese calligraphy current named "Few Characters" (shaozishu) ${ }^{13}$. As GU Gan (2000) explained, modernist calligraphers focus on the use of few essential characters imbued with high aesthetic values, because their aim is to combine aesthetic pleasure and meaningful content. Chinese characters become something similar to "symbols" which enlighten the viewers' minds, in a way they can understand the meaning of what they are contemplating even if they do not know the linguistic meaning. Of the four script forms, they prefer the cursive and the seal scripts rather than the others. They use the cursive script (caoshu) because it is the most abstract one, and the seal script (zhuanshu) because it is the most pictographic one. For example, the Taiwanese woman calligrapher TONG Yang-tze (b. 1942) uses the cursive script, and more specifically the "wild cursive script" (kuangcao), inspired by the Tang calligrapher HUAI Su (737?-799?) (see Figure 6), while the Sino-Australian calligrapher HUANG Miaozi uses the seal script, combined with brilliant colors and geometric schemes inspired by native Australian art (see Figure 7).

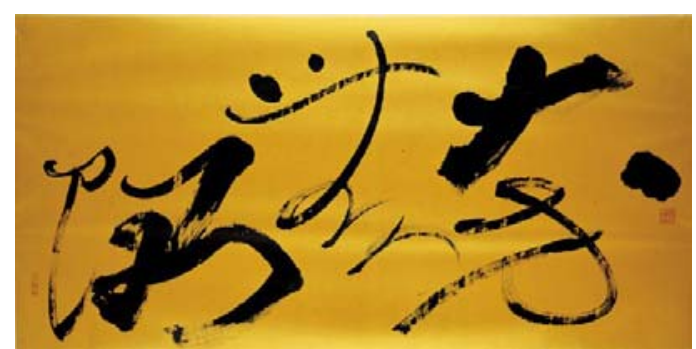

Figure 6. TONG Yang-tze, A Perfect Square Has No Angles (Da fang wu yu 大方无隅) (2007), ink on gilded paper,

$137 \mathrm{~cm}$ x $69 \mathrm{~cm}$, Goedhuis Contemporary Gallery. Source: Goedhuis Contemporary Gallery website.

\footnotetext{
${ }^{13}$ The influence of contemporary Japanese calligraphy on the Chinese counterpart is enormous, especially since 1972, when the diplomatic relations between the two countries were re-established. Many exhibitions on contemporary Japanese calligraphy took place in China from 1977 to 1985: (1) in 1977 and in 1982, two group exhibitions on contemporary Japanese calligraphy; (2) in 1982 an exhibition on contemporary Japanese seals; (3) in 1983, another group exhibition on the artistic and calligraphic interchanges between the two countries; and (4) finally in 1985, a solo-exhibition of the famous Japanese calligrapher Teshima Yūkei (1901-1987), the leader of the "Few Characters" current. This current, characterized by the use of few characters or only one character for each calligraphic work, was focused on the experimentation in the use of ink effects and in the spatial arrangement of the composition. For more details on this current, see: ZHENG, L. Y. \& CAO, R. C. (1986). Japanese Modern Calligraphy (Riben xiandai shufa 日本现代书法), pp. 125-134. The influence of Japanese calligraphy is so relevant for the Modernist movement because most of the modernist calligraphers stayed in Japan for months or years, for example, WANG Xuezong from 1982 to 1984, and WANG Dongling from 1993 to 1994.
} 


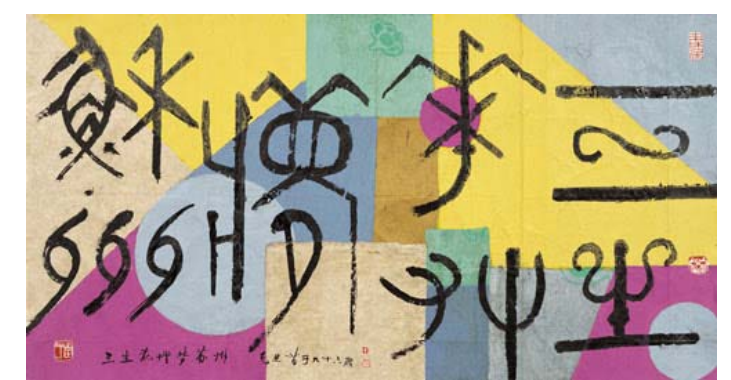

Figure 7. HUANG Miaozi, Dream of Flowers, Plants and the Three World Ages in Suzhou (2009), ink and color on paper, $75 \mathrm{~cm}$ x $140 \mathrm{~cm}$, private collection. Source: Photographed by the author.

The contamination of styles is another important feature of the Chinese modernist movement, which is strongly influenced by Western art, especially by the Western Abstract art. This contamination is clearly visible in all of the modernists' artworks, for example, in LI Luogong's pictures, deeply influenced by Fauves artists, especially by the French painter Maurice de Vlamnick; or in WANG Dongling's calligraphies, strongly influenced both by European Abstract art, particularly by the Russian painter Vassily Kandinsky, and American post-World War II art movements; and also in GU Gan's paintings, admirably contaminated by the works of Paul Klee (see Figures 8-9) and Antoni Tàpies.

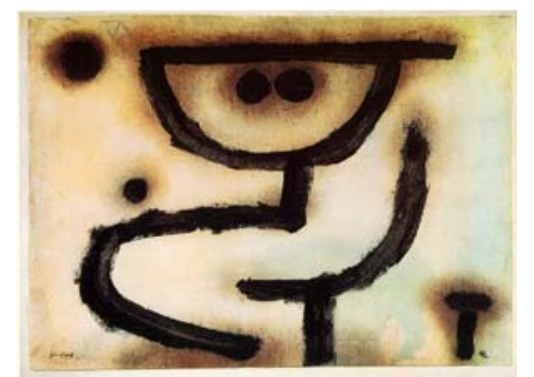

Figure 8. Paul Klee, Embrace (1939), pastel, watercolor and oil on canvas, $232 \mathrm{~cm}$ x $234 \mathrm{~cm}$. Hanover, Dr. B. Sprengel collection.

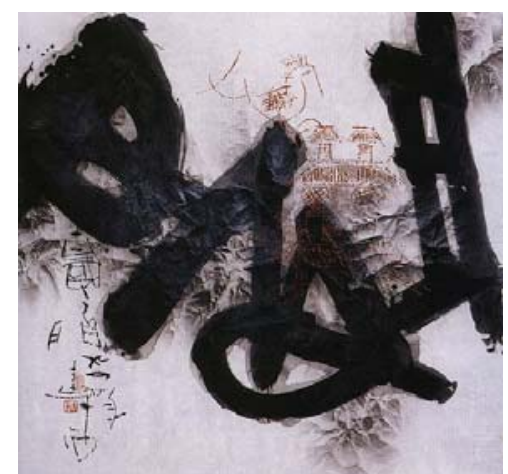

Figure 9. GU Gan, Opening up (Kai yi guguo zhi men 开一古国之门) (1995), mixed media,

$99 \mathrm{~cm}$ x $101 \mathrm{~cm}$. London: British Museum. Source: Barrass (2002, p. 189).

Finally, as Z. J. LIU (1999) noted, another important characteristic of the modernist movement is the pictorial approach to calligraphy. In this case, the modernists try to exploit the full range effects that have long been known to Chinese painters, including the use of colored ink, or flecked ink with water, in order to obtain stratified ink effects. They have also never rejected the use of the "Four treasures of the study" (wenfangsibao), 
such as paper, writing brush, ink stick, and ink stone, that are the traditional tools of all Chinese calligraphers and painters, even if they sometimes make small changes in their use: Tong Yang-tze, for example, usually writes on gilded paper instead of white/plain paper (see Figure 6), GU Gan experiments with the use of acrylic paint on paper and wood (see Figure 9), and WANG Dongling is famous for his calligraphy made on newspaper collage (see Figure 10) or on magazine sheets (see Figure 11).

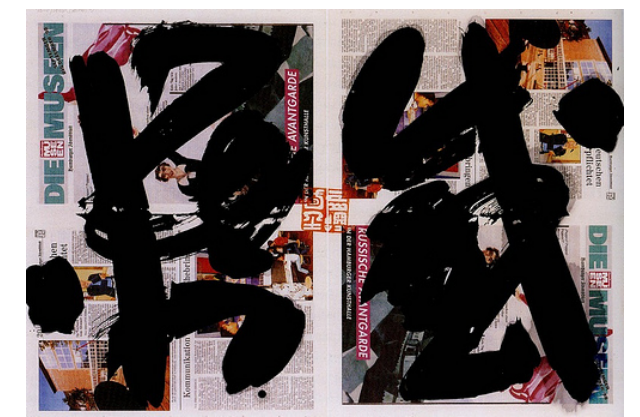

Figure 10. WANG Dongling, Feeling and Passion (1999), ink on newspapers, $56 \mathrm{~cm}$ x $81.2 \mathrm{~cm}$, London: British Museum. Source: Barrass (2002, p. 168).

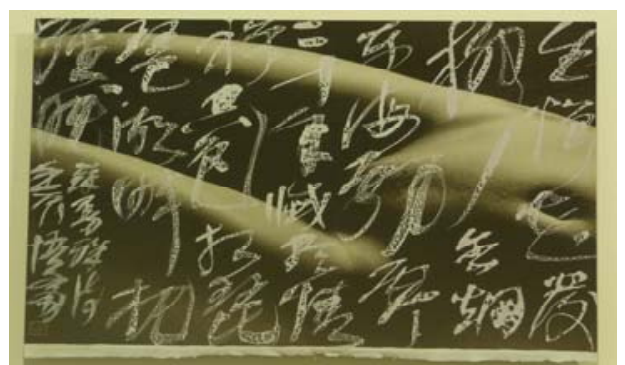

Figure 11. WANG Dongling, Untitled (2012), white ink on a magazine sheet of paper,

$21 \mathrm{~cm}$ x $30 \mathrm{~cm}$, artist collection. Source: Photographed by the author.

In conclusion, in the works of all Chinese modernist calligraphers, tradition and contemporary features are completely combined and intermingled, and this is true not only for their theoretical conception but also in their formal execution and artistic practice.

\section{The Avant-Garde Movement}

The Avant-garde movement, instead, points out that "Contemporary calligraphy is not calligraphy yet" (Xiandai shufa bu shi shufa), as Professor WANG Nanming wrote in his book entitled Understanding Modern Calligraphy (Lijie xiandai shufa) (1994). To this movement, contemporary calligraphy is a sort of “anti-calligraphy” (N. ZHANG, 1999; Q. G. QIAN, 2002; X. JIANG \& D. L. WANG, 2005; L. F. QU, 2008), because it produces a kind of de-construction of traditional calligraphy, in a sense, a sort of negation of it. According to Professor N. M. WANG (2005), "What links contemporary calligraphy to the traditional one is its radical opposition to it" (p. 12). In contrast with WANG Dongling's point of view, he sustains that contemporariness of an art always means the subversion of the tradition. In WANG Nanming's opinion, CCC is an independent Avant-garde form of art, which is particularly influenced by the Western Abstract expressionism. This means that contemporary calligraphy is not discussed with reference to the self-sufficient system of calligraphy, but is considered in terms of a modern Avant-garde form in isolation of calligraphy. N. M. WANG (2005) also believed that the function of calligraphy in contemporary calligraphy is more to meet a "need of 
'hinting"" ("anshi" de xuyao, p. 12) than to prove the value of calligraphy itself. In other words, contemporary calligraphy not only has connection with their tradition but also appears as an opponent. Failure to realize this point results in the so-called inappropriate "modern" or "Avant-garde" calligraphy. To him, "the concept of 'contemporary calligraphy' is only a temporary/transitional concept" (N. M. WANG, 2005, p. 12), because it mirrors only the time when it is used. Therefore, he sustains that it is necessary to overshoot this inadequate concept and explore new linguistic possibilities. To support his theory, he then analyzes the works of contemporary Chinese artists, such as CHEN Guangwu (b. 1967) and WU Wei (b. 1963), that he considers "post-abstract" and "Conceptual art" calligraphers.

According to WANG Nanming's analysis (1994), the Avant-garde Art breaks with the tradition completely, aims at a radical, total transformation of calligraphic art, rejects the use of legible characters, and experiments with new languages and new media within the idiom of international contemporary art. All this, in order to challenge conventional thinking and, above all, to make people reflect upon human condition. As GAO Minglu explained (1998), in the Avant-garde Art: "The most influential artistic and philosophical sources were Dada ${ }^{14}$ and traditional Chan (Zen) Buddhism. [...] The influence of Chan Buddhism, which like Dada, attempts to break free from any doctrine, dogma, text, or authority" (p. 159).

In the details, two main currents characterize the Avant-garde movement: The first one, called with different names, such as "Endgame art" (Chang Tsong-zung, as cited in Sullivan, 1996, p. 279), "art-and language movement" (Bryson, 1998, pp. 51-58), and "Conceptual art" (M. L. GAO, 1998, pp. 158-166), particularly focuses on the deconstruction of the writing system and language (the artists GU Wenda, XU Bing, WU Shanzhuan, and QIU Zhijie belong to this sub-current); while the second one focuses especially on the calligraphic line, intending it as the performance in itself and as its abstract beauty as well (the artists WEI Ligang, PU Lieping, QIN Feng, ZHANG Dawo, ZHANG Qiang, etc., belong to this other sub-current).

It is interesting to note that while traditional calligraphy has always been simultaneously a "verbal art" and an "Abstract art" (Y. G. ZHANG, 1998), the "art of writing characters" (xiezi yishu) and the "art of writing lines" (xiantiao yishu) (C. M. LIU, 2010), in the Avant-garde view, instead, calligraphy splits into these two parts and becomes a "verbal art" or an "Abstract art", the "art of writing (un-meaningful) characters" or the "art of writing (painting-like) lines". If it becomes a "verbal art", its aim is the deconstruction and the annihilation of the Chinese writing system that becomes unreadable and meaningless; the aesthetic flavour and the abstract beauty of the line and of the calligraphy composition are no longer important and the artists focus on the concept behind the artwork. On the other hand, if it becomes an "Abstract art", and the artists try to forget the connection between calligraphy and language. Although they give up the system of Chinese written characters, they do not shake off the structural composition and the formal pattern arranged on the "calligraphic line". In this way, the aesthetic perception is similar to the structure of Chinese characters and to the structural composition of a piece of traditional calligraphy, but no characters have been written, and no texts can be read. The result is something more similar to abstract painting than to calligraphic work. In both cases, the artworks do not have "written characters with meaning" that could interfere with the pure visual image. This means that signs no longer belong to the "code of readable written

\footnotetext{
14 The Rauschenberg's solo-exhibition which took place in Beijing in 1985 was foundamental for the Avant-garde movement. The exhibition, entitled “Rauschenberg's International Traveling Exhibition” (Laosenboke zuopin guoji xunhuizhan 劳森伯格作 品国际巡回展), was held at the National Art Museum of China from November 18 to December 8, 1985.
} 
language" (only understandable by a Chinese audience), but in the first case to the "code of rational thoughts" and in the second case to the "code of emotional feeling" (Q. G. QIAN, 2002, p. 56) that can appeal respectively to "the ability to reflect and question" or to "the aesthetic sense" of contemporary people all over the world. In this way, from being a local form of art, calligraphy opens itself to the global comprehension.

The differences between the modernist and the Avant-garde movements are also evident: For the modernists Chinese tradition is fundamental; while for the Avant-garde artists, it is only an important part of their educational training, it is the starting point of their art, but it is not involved in the creative process, except in cases of opposition to it. In the Avant-garde practice, traditional tools are usually replaced with new methods and new media, such as photography, computer technology, Performance art, video art, etc.; and the influence of Western art, especially of Western modern and contemporary art, is wide-ranging and extremely productive, and it is not only limited to Abstract art.

As a result of all this, the Chinese Avant-garde movement becomes international, because it creates new works of art that cannot be assimilated to the self-sufficient system of traditional calligraphy, as WANG Nanming has aptly observed (see above). The author thinks that they should be assimilated to universally comprehensible forms of art, closely connected with Western art, such as Abstract art, Abstract expressionism, Conceptual art, Performance art, Contemporary dance, Multimedia art, and even Street art/Graffiti art (see Figure 12).

\section{MAIN TENDENCIES OF THE AVANT-GARDE MOVEMENT}
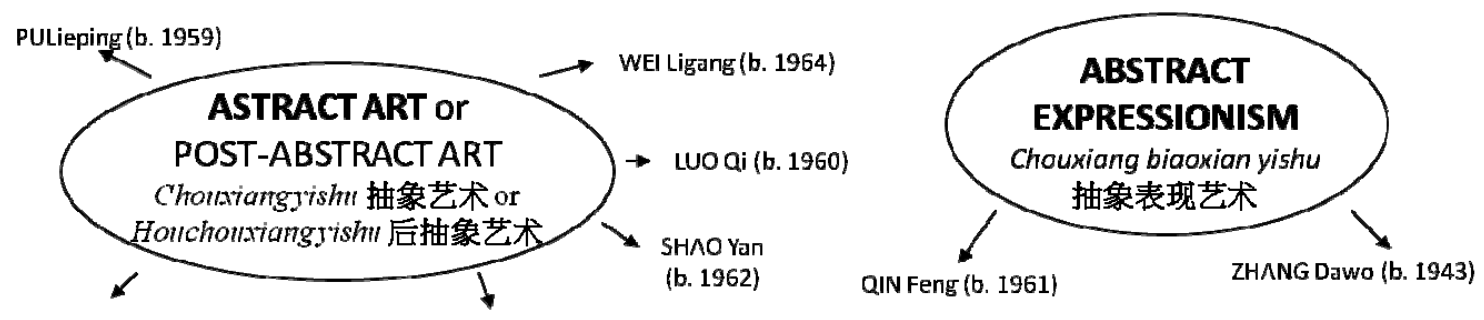

FUNG Ming Chip (b. 1951) CHENG Guangwu (b. 1967)
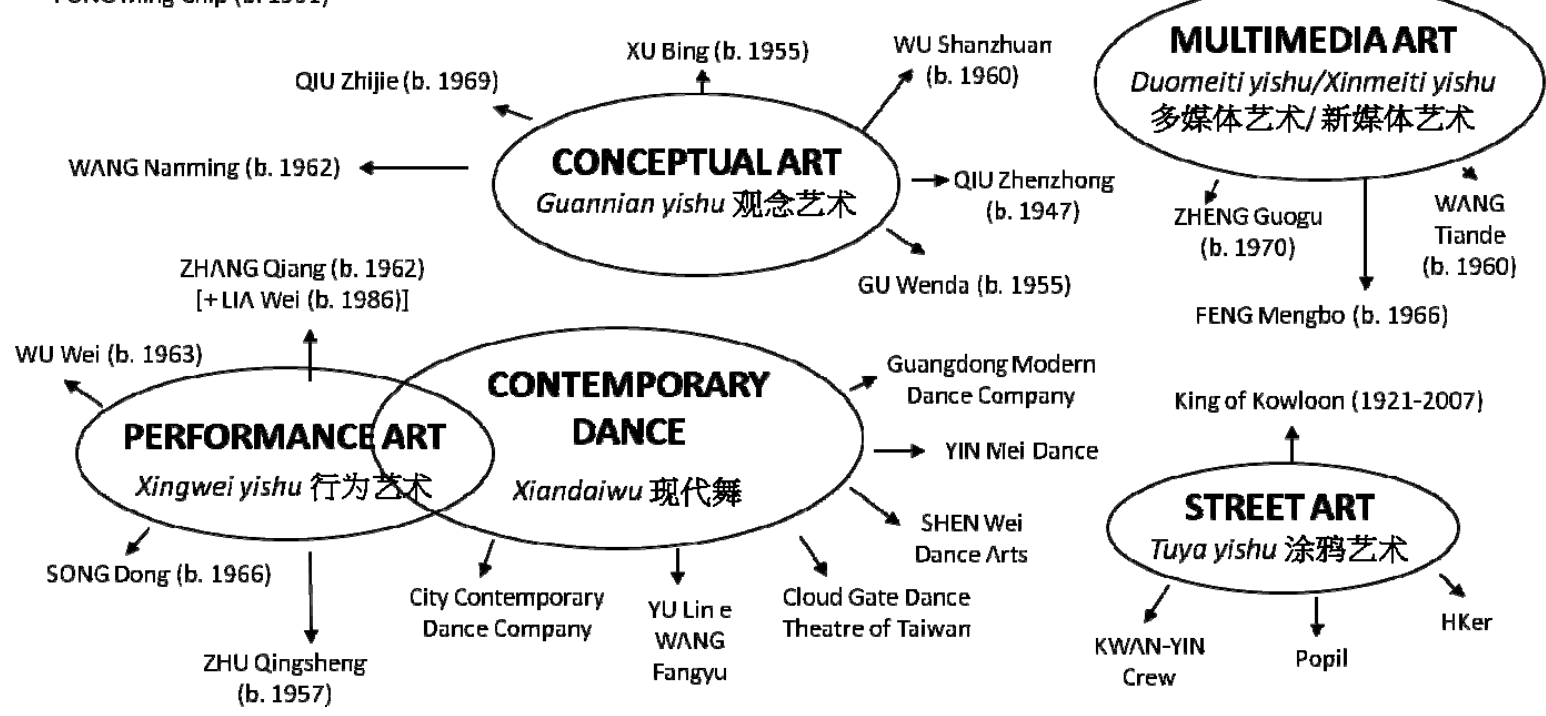

Figure 12. A schematic model of the main tendencies of the Avant-garde movement arranged by the author. 
It is important to clarify that this categorization is not completely fixed and has not rigid frame, but it is flexible and dynamic, because it reflects the contemporariness of international Avant-garde art. This means that the above mentioned artists can simultaneously belong to more than one category, because their works can share the characteristics belonging to different categories. Because they are all-around artists, they not only create work of art that has connection with the art of calligraphy, but they have been selected by the author, because the reflection upon the art of calligraphy is the major (or one of the major) topic of their artistic fatigue. So, in the author's intention, this is only an attempt to systematize an extremely complex and vividly debated subject.

As to Abstract art, it is of utmost importance to note that contemporary Chinese artists, belonging to both modernism and Avant-garde movement, are clearly influenced by Western Abstract art, even if in different ways. In modernists works, we can still recognize the shape of Chinese characters, for example in GU Gan's picture, inspired to the European artist Paul Klee (see Figures 8-9), while in Avant-garde artists we can only contemplate the outstanding beauty of the line, for example in PU Lieping's picture, inspired to Mirò's works, or in WEI Ligang's picture, influenced by Paul Klee and Brice Marden's works (see Figures 13-15).

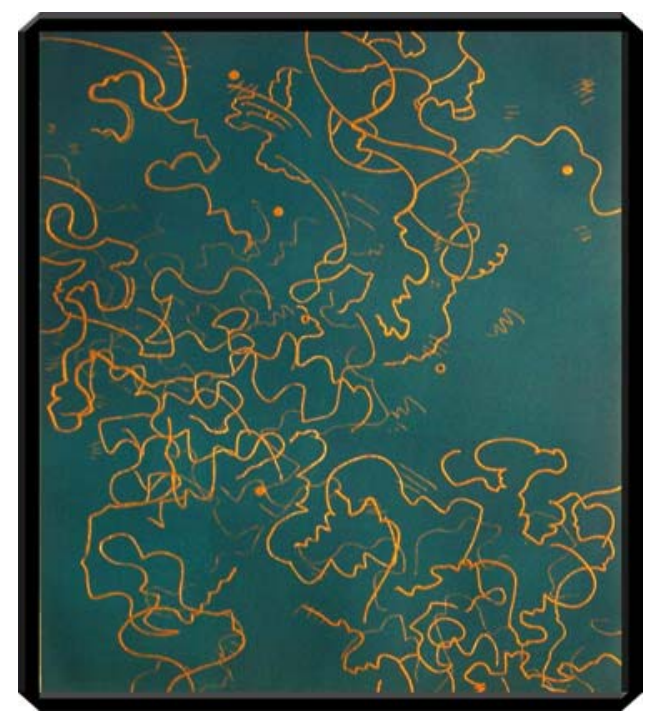

Figure 13. Paul Klee, Viscosity Etching III (1930 ca.), $14 \mathrm{~cm}$ x $11 \mathrm{~cm}$, private collection.

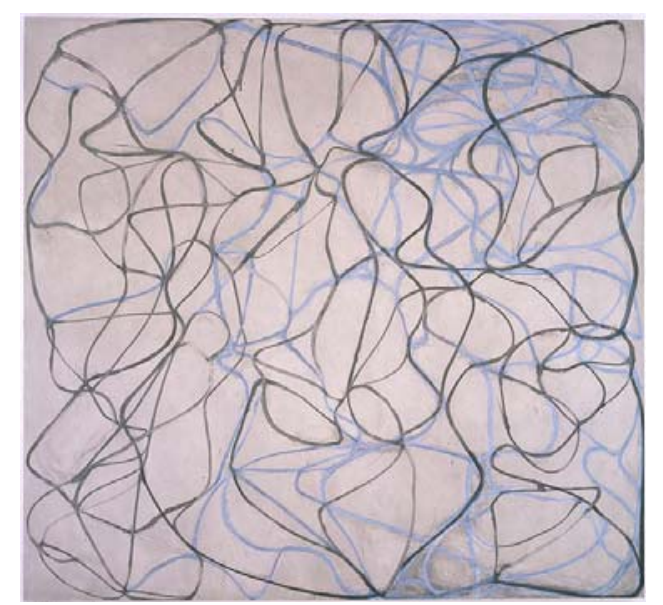

Figure 14. Brice Marden, Vine (1992-1993), oil on flax canvas, $240 \mathrm{~cm}$ x $255 \mathrm{~cm}$, New York: Museum of Modern Art. Source: MoMA website. 


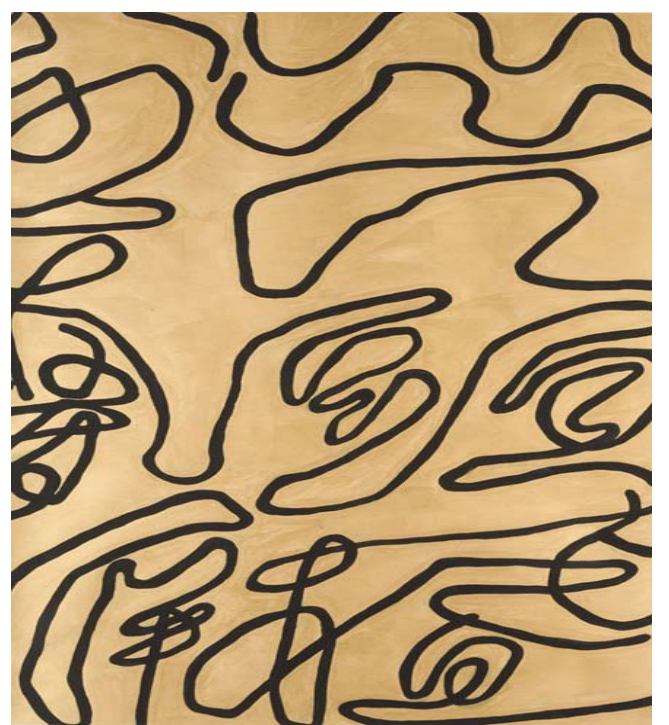

Figure 15. WEI Ligang, Odiferous Thornbush Near Headstream and Flying at Riverbank (detail) (2008), ink and acrylic on paper, $198 \mathrm{~cm}$ x $250 \mathrm{~cm}$, Goedhuis Contemporary Gallery. Source: Goedhuis Contemporary Gallery website.

As to Abstract expressionism and its influence on Chinese Contemporary artists, it would be useful to read what Sullivan (1973) wrote about Abstract expressionism and CCC:

Abstract expressionism and Action Painting put the Oriental painter in a totally new relationship with Western art. Now suddenly calligraphic abstraction became respectable. [...] It was the impact of the New York school after the war that drove them to discover, or rather to rediscover, the Abstract Expressionist roots of their own tradition. Art since 1945 has in any case become, and today the stimulus is likely to go from East to West as in other direction. The complaint that the work of some Oriental painters is no longer really Oriental has ceased to have any meaning. (pp. 179-180)

This is especially true for Chinese Abstract Expressionist calligraphers, like, for example, QIN Feng (b. 1961) (see Figure 17) and ZHANG Dawo (b. 1943) (see Figure 18), which styles have been visibly contaminated by the Western Abstract Expressionist artist Franz Kline (see Figure 16).

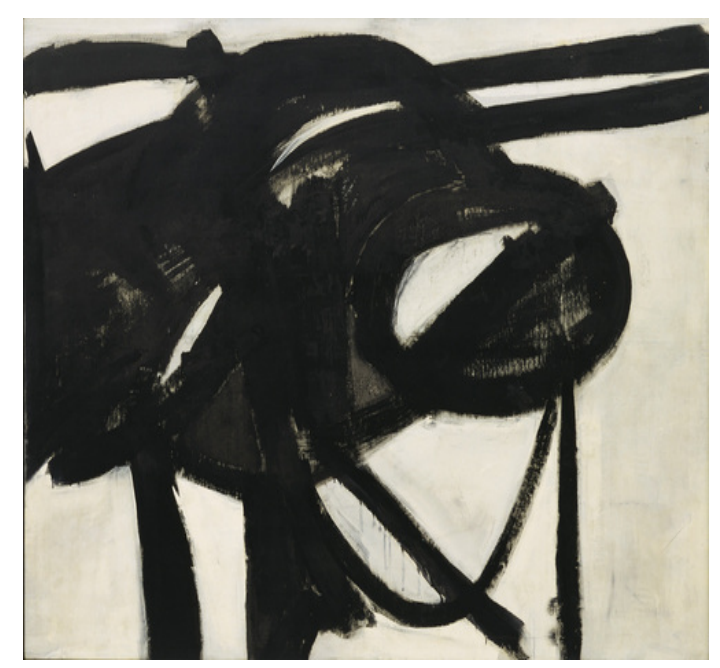

Figure 16. Franz Kline, Chief (1950), oil on canvas, $148.3 \mathrm{~cm}$ x $186.7 \mathrm{~cm}$, New York: Museum of Modern Art. Source: MoMA website. 


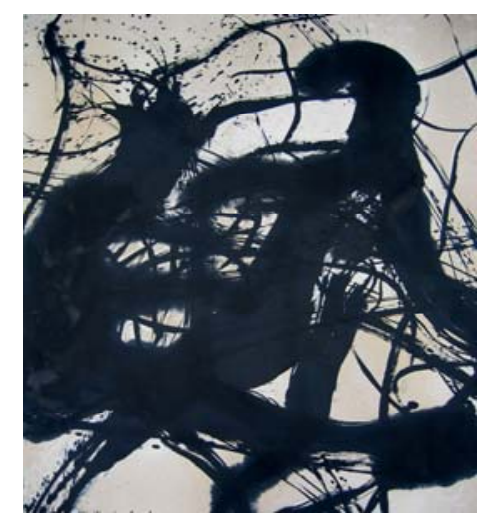

Figure 17. QIN Feng, Civilization Landscape (2004), ink on silk and fiber paper, $140 \mathrm{~cm}$ x $400 \mathrm{~cm}$, collection of the artist. Source: QIN Feng official website.

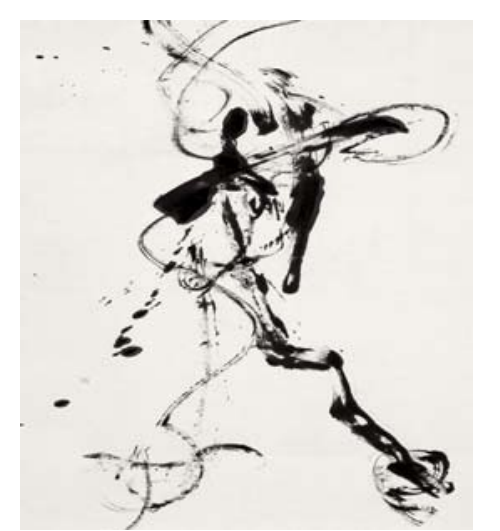

Figure 18. ZHANG Dawo, The Star of the City, a Rock and Roll Singer (2011), ink on paper, $162 \mathrm{~cm}$ x $94 \mathrm{~cm}$, private collection. Source: ZHANG Dawo official website.

As to Conceptual art, the main representative artists are XU Bing and GU Wenda, that have been already analyzed before as the authors of Book from the Sky and The Mythos of Lost Dynasties; QIU Zhenzhong and WU Shanzhuan, that have been already named before as the authors of The First Four Series and The Red Humor; QIU Zhijie (b. 1969), who, for example, invented the so-called "light-calli-photography" (S. M. GAO, 2006, p. 11) (see Figure 19), which transforms the traditional calligraphy practice through the use of flash-light (the brush) and colored photography (the ink and the paper); and eventually WANG Nanming, who shaped his Combinations of Balls of Characters (see Figure 20), composed by the balls of rejected paper that he accumulated during his calligraphy practice.

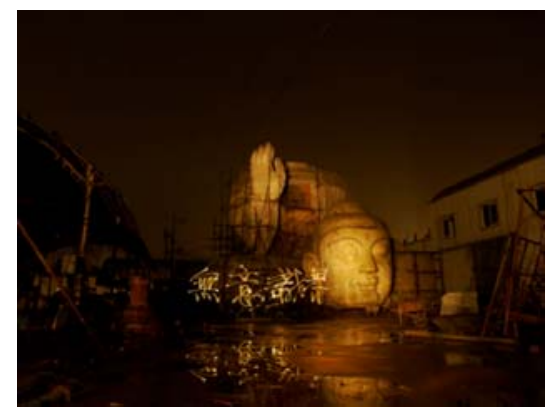

Figure 19. QIU Zhijie, Lightwriting: The Heart Sutra n. 22 (Guangxie shufa: Xin Jing n. 22 光写书法: 心经 22) (2005), photograph, $133 \mathrm{~cm}$ x $100 \mathrm{~cm}$, collection of the artist. Source: QIU Zhijie official website. 


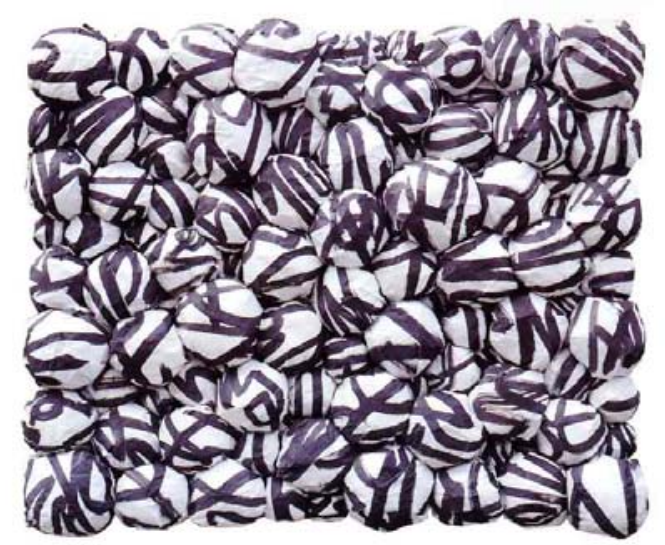

Figure 20. WANG Nanming, Combination: Ball of Characters (1992), ink on paper, $120 \mathrm{~cm}$ x $100 \mathrm{~cm}$, Pusan Metropolitan Art Museum. Source: N. M. WANG (1994, cover of the Understanding modern calligraphy).

Reflection on calligraphy is also the starting point for many Chinese performers. For example, this is clearly visible in the works of ZHANG Qiang (b. 1962), who is the founder of the so-called "traceology" (Zongjixue, see more in Q. ZHANG, 2006), the method he always uses in his calligraphic performances, centred on enlisting the aid and the active collaboration of a female partner in creating his works (see Figure 21). In 2008, he also founded the "Biface Group" with a Belgium woman artist, Lia WEI (b. 1986) (see Figure 22); since then they create monumental site-specific installations of huge panels entirely covered by calligraphic lines (see Figure 23) (see more in Q. ZHANG \& WEI, 2012). Other important performers who connect their artistic practise with calligraphy conceptions are the world-famous SONG Dong (b. 1966) and ZHANG Huan (b. 1965).

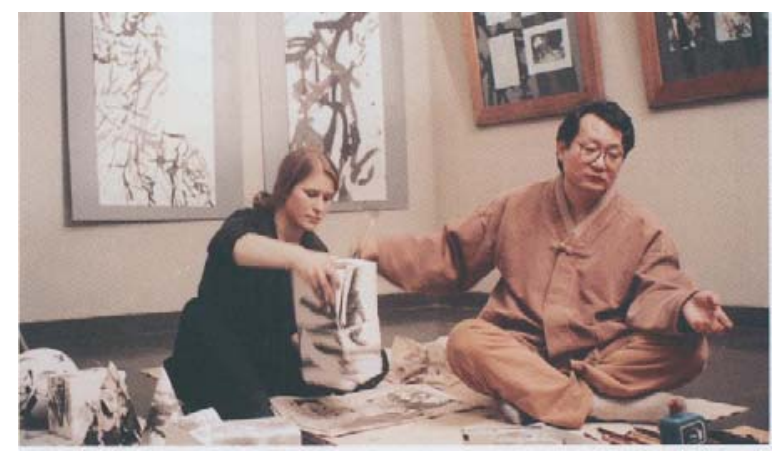

Figure 21. A calligraphic performance by ZHANG Qiang. Source: Barrass (2002, p. 256).

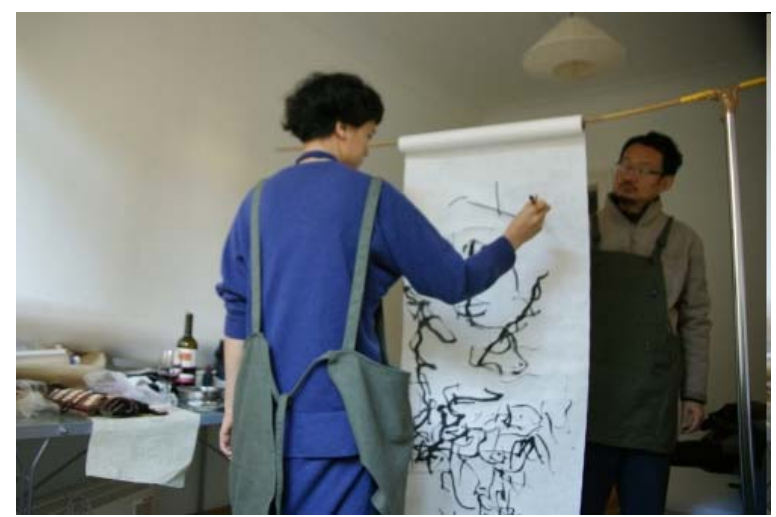

Figure 22. Biface Graphy at work. Source: Q. ZHANG and WEI (2012, p. 74). 


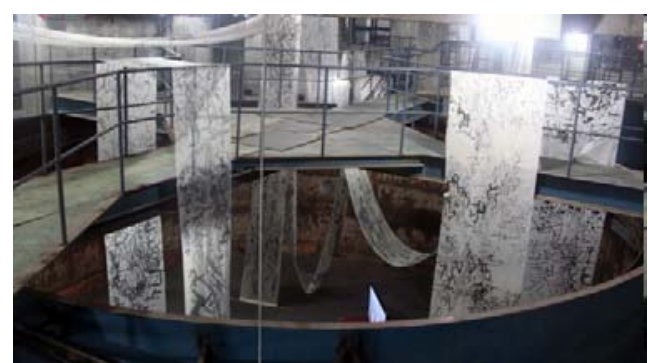

Figure 23. Biface Graphy, Flying White (Feibai 飞白) (2011), mixed media installation, Chengdu. Source: Q. ZHANG and WEI (2012, p. 44).

Calligraphy is also a source of inspiration for many contemporary Chinese dance companies: First of all, for the Cloud Gate Dance Theatre of Taiwan which staged three ballets, entitled "Cursive I" (2001), "Cursive II" (2003), and "Wild Cursive" (2005), totally inspired by calligraphic movements, and in particular by cursive script rhythm (see Figure 24). Other companies who take inspiration from calligraphy for their choreographies are the Guangdong Modern Dance Company in mainland China, the Shen Wei Dance Arts and the Yin Mei Dance in New York, and even the City Contemporary Dance Company in Hong Kong. It is interesting to note that these companies have their headquarters not only in mainland China but also abroad (Taiwan, Hong Kong, and United States).

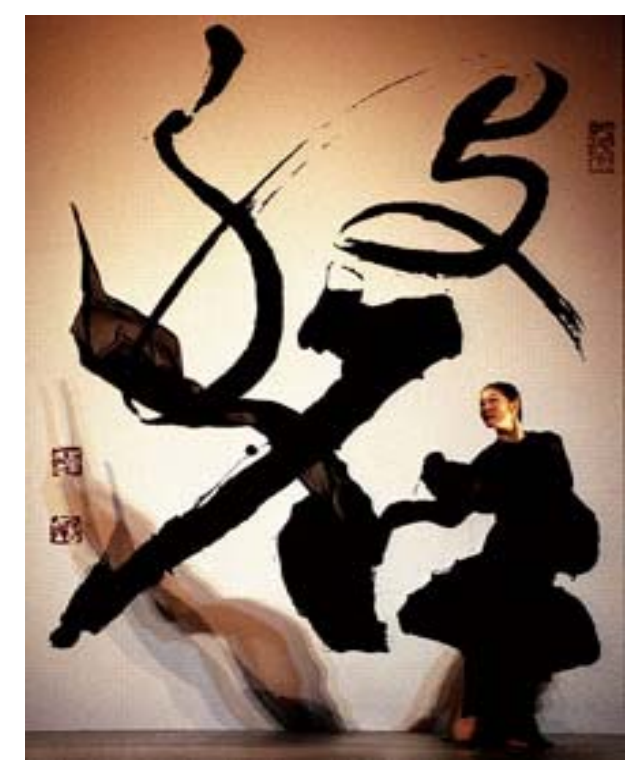

Figure 24. Cloud Gate Dance Theatre of Taiwan, Cursive I (2001). Behind the dancer, the Tong Yang-tze's work entitled Pan 磐 (Hard Stone) is part of the backdrop. Source: Cloud Gate Dance Theatre of Taiwan website.

As to Multimedia art, the most experimental artist in the field is undoubtedly FENG Mengbo (b. 1966). In his work he connects calligraphy with computer software, GPS (Global Position System) technology and even video-game. For example, in his work entitled The Invisible Words: A GPS Calligraphy Project (2006) (see Figure 25), he uses GPS technology to "write" Chinese characters across city maps and oceanographic charts. The artist travels the route (in "kilometres' long brush strokes") determined for him by the shape of an ideogram and records the result as he goes. Then, in one of his last works, entitled Not too Late (2010), he adds the element of Chinese calligraphy to a video-game. Based on the concept of Quake III Arena, he creates his 
own MOD (modification), in which the time frame is totally slowed, so that the trajectory of the slowly movement is clearly visible on the screen. As a consequence, the scenes are not as violent and bloody as in the original game, and the trajectory of bullets and fire is largely preserved, but the scene looks like a calligraphic masterpiece (see Figure 26).

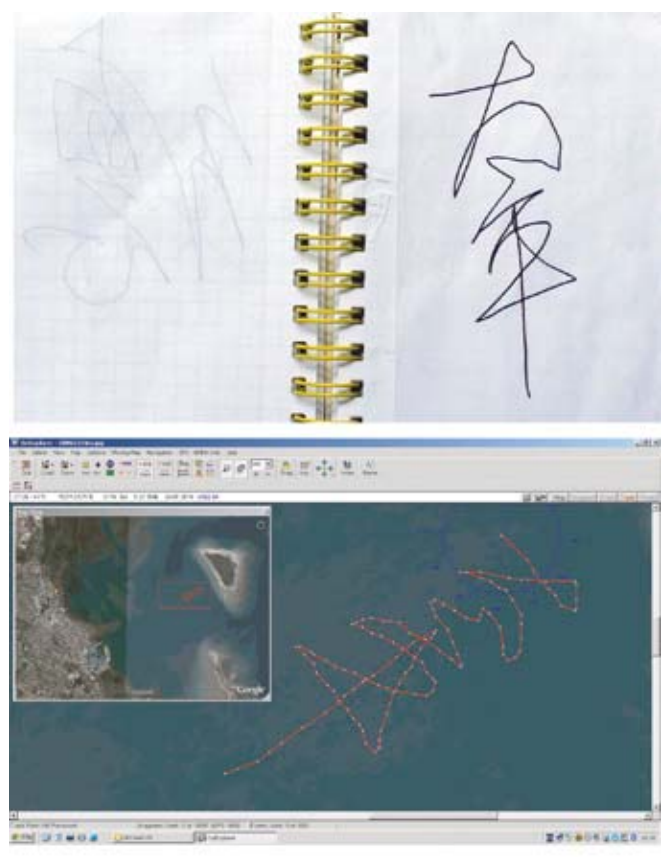

Figure 25. FENG Mengbo, The Invisible Words: A GPS Calligraphy Project (2006), mixed media (Moreton Bay, November 2006).
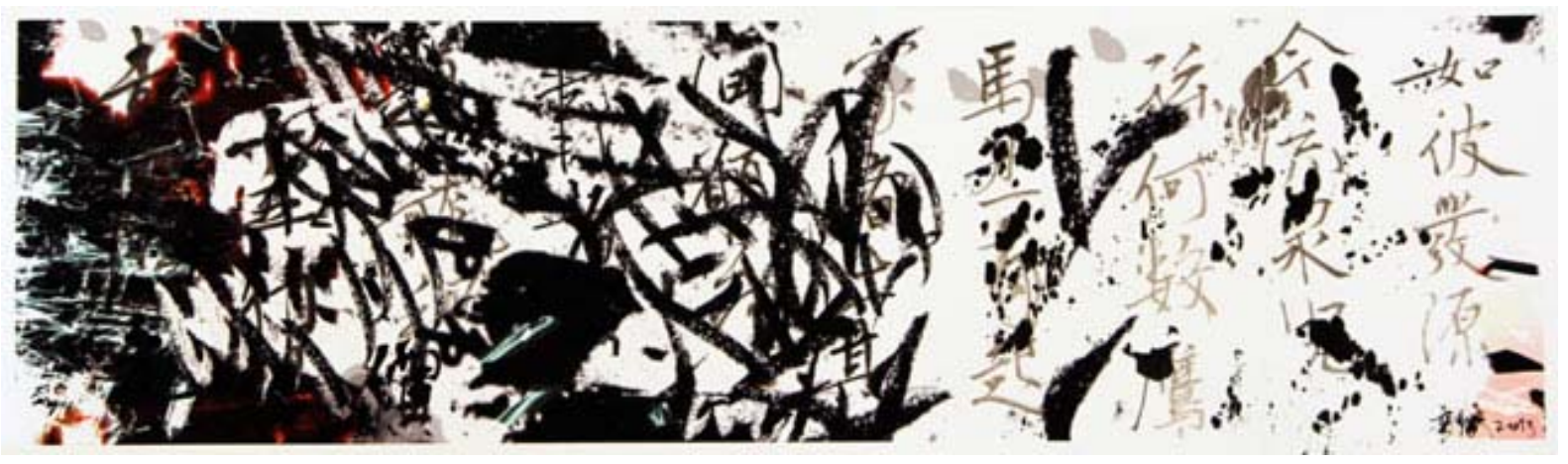

Figure 26. FENG Mengbo, Not too Late (Bu tai wan 不太晚)—Shot 0107 (2013), ink and archive grade inkjet on

Hahnemühle Museum Etching Paper, $24 \mathrm{~cm}$ x $88 \mathrm{~cm}$. Source: Chamber of Fine Art website.

The influence of Chinese calligraphy practise in the Avant-garde art is evident even in Street art/Graffiti art. The most remarkable examples in this field are the "calligraphy graffiti" (see Figure 27) by Tsang Tsou Choi, the so-called "King of Kowloon" (1921-2007) in Hong Kong: Executed using brush and ink, his graffiti have been spotted at many places on the streets of Hong Kong (lampposts, utility boxes, pillars, pavements, street furniture, and building walls), and they recorded his complaints about the supposed misappropriation of his land by the government itself. On the other hand, in mainland China, in the works of some of the most famous Chinese Street art crews, such as the KwanYin Clan in Beijing, Popil and Dezio in Shanghai, and The Kong 2 Crew in Changsha, 
the attempt to blend the art of Western bomb-lettering and the art of Chinese calligraphy is clearly visible and extremely successful (see Figure 28).

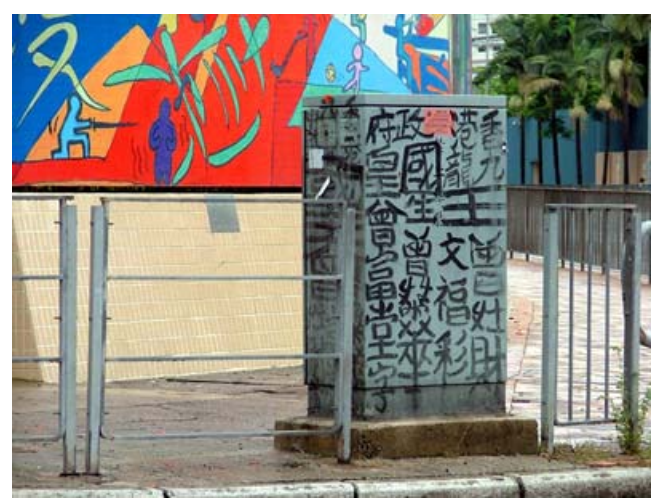

Figure 27. King of Kowloon: One of his works on a utility box in Hong Kong.

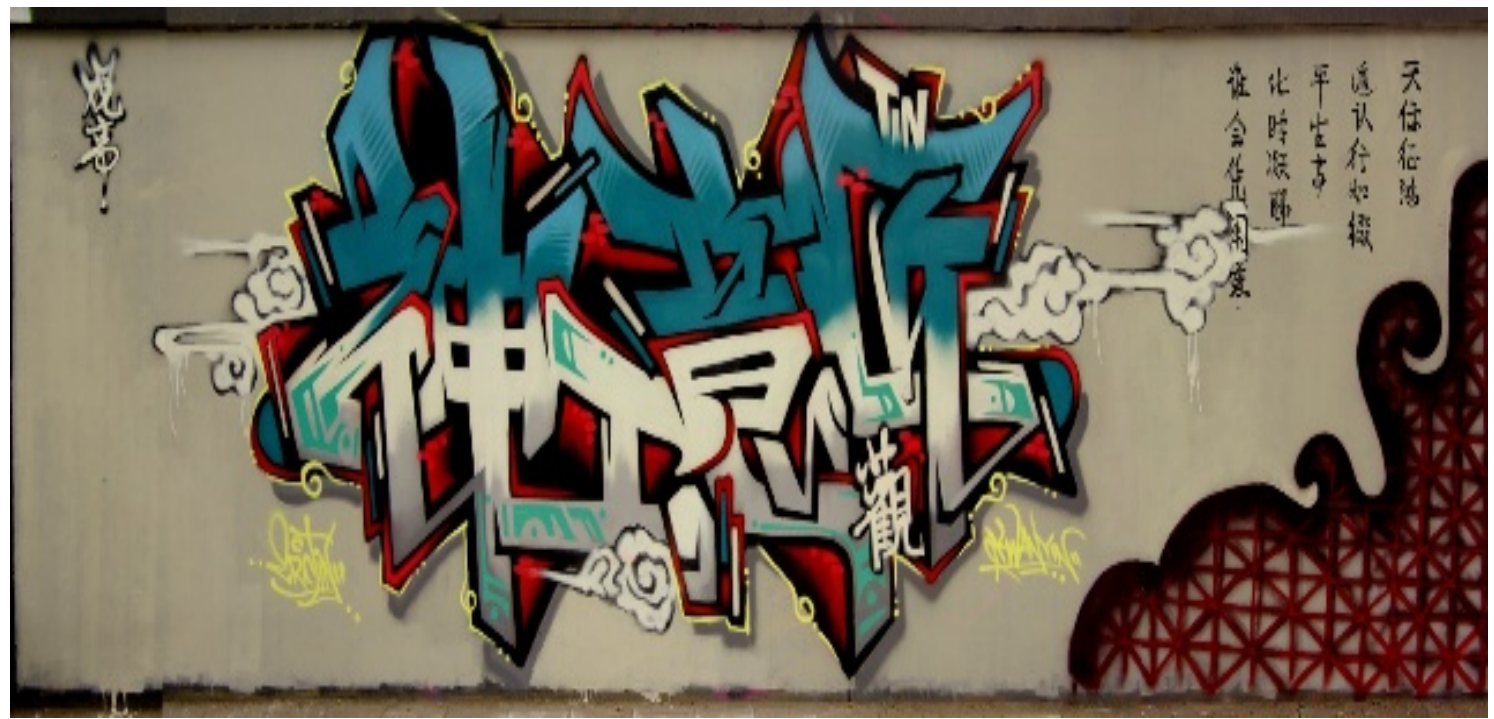

Figure 28. KwanYin Clan-TIN, Shen gong yi jiang 神工意匠 (New Artistic Creation) (2010), graffiti on wall, Beijing. Source: KwanYin Clan official blog.

\section{Conclusions}

As it has just been shown, the art of calligraphy is still extremely productive in China nowadays, especially through the Modernist and Avant-garde movements. Even if with different theoretical and practical/creative approaches, fully and aptly analyzed by Professor WANG Dongling (see above) and Professor WANG Nanming (see above), both the movements reflect the main aim of Chinese contemporary society at dialectically facing their past tradition and at opening to a new one as well.

Because the essence of both movements lies in their variability, they stress difference, emphasize contemporariness, and try to fuse many diverse methods, types, and styles of art, thereby breaking with historical practice and opening to foreigner influences. These influences, even if of different origins (from Japanese modern calligraphy and Abstract art in the Modernist movement, and from Western conceptual and experimental art in the Avant-garde movement), encourage greater expressive freedom, thereby affording more direct artistic accessibility. The result is that all of the works presented can be appreciate quickly and world-wide: In the 
modernists' works, even if the content of words usually continues to be dependent on the artistic form, the emphasis is on the spatial elements and of the pictorial and architectural use of lines, dots, and colors, that appeal directly to everyone eyes; on the other hand, in the Avant-garde works, the outstanding beauty of the line, the conceptual idea behind the work, and the use of new methods and new media, completely independent from the linguistic content, freely open to the world-wide comprehension. In all of these works, the artists try to combine different types of calligraphy and different types of art, thus rendering calligraphy even more complex and more difficult to identify, as the art critics point out. Seeking greater variation of artistic form, the art of calligraphy changes its characteristics and becomes only a segment of the creative process, even if the most important one.

In fact, for all the artists presented, Chinese calligraphy represents the starting point but not the finishing line of a creative process. Reflecting new social realities in China itself and new perspectives in global art world, their approach is closer to cotemporary aesthetics than to traditional practice, but both of the elements are essential to understand the present and unprecedented developments of this most traditional art. Theirs are, above all, an attempt to create a new artistic language that can turn the art of calligraphy into a medium for communication and global comprehension.

\section{References}

Barrass, G. (2002). The art of calligraphy in modern China. London: British Museum Press.

Bessire, M. (Ed.). (2003). Gu Wenda: Art from middle kingdom to biological millennium. London: MIT Press.

Bryson, N. (1998). The post-ideological avant-garde. In M. L. GAO (Ed.), Inside out-New Chinese art. Berkeley: University of California Press.

CHANG, T. Z. (1993). Introduction. In V. C. Doran (Ed.), China's new art, post-1989, with a retrospective from 1979-1989. Hong Kong: Hanart TZ Ltd..

CHEN, D. Z. (2005). A research on contemporany Chinese calligraphy artistic groups and a categorization of their creative work (Dangdai shufa chuangzuo moshi yu pailiu yanjiu 当代书法创作模式与派流研究). Beijing: Rongbaozhai Press.

CHENG, M. X. (2006). A first exploration of "modern calligraphy": Creative patterns and theoretical thoughts ("Xiandai shufa" chuangzuo siwei moshi chutan “现代书法” 创作思维模式初探). In B. WEN \& J. C. SU (Eds.), Collection of accademic essays about modern Chinese calligraphy of the last 20 years (Zhongguo xiandai shufa 20 nian xueshu yanjiuhui lunwenji 中 国现代书法20年学术研究会论文集). Hong Kong: Hong Kong Oriental Art Centre.

Chiu, M. (2002). The crisis of calligraphy and the new way of tea: An interview with wenda gu. Orientations, 3.

Erickson, B. (2001). Words without meaning, meaning without words: The art of Xu Bing. Seattle: University of Washington Press.

FU, J. S. (1998). Typologies of contemporary Chinese calligraphy (Zhongguo xiandai shufa de leixing ji qiwen 中国现代书法的 类型及其文). Meishu guancha, 6.

FU, J. S. (2011). The shape of chinese modern calligraphy (Zhongguo xiandai shuxiang 中国现代书象). Beijing: Culture and Art Press.

GAO, M. L. (2000). The '85 Movement: Avant-garde art in the post-Mao era. Cambridge: Harvard University Press.

GAO, M. L. (Ed.). (1998). Inside out-New Chinese art. Berkeley: University of California Press.

GAO, S. M. (2006). A momentary pause in anomalous and everyday lives: Comments on the work of Qiu Zhijie. In C. W. MAO (Ed.), The shape of time: The calli-photo-grapy by Qiu Zhijie. New York: Chambers Fine Arts.

GAO, T. M. (2004). The meaning of “Modern Calligraphy” (“Xiandai shufa” de hanyi“ 现代书法” 的含义). In D. L. WANG (Ed.), Florilegium of theses on contemporary Chinese calligraphy (Zhongguo “Xiandaishufa” lunwen xuan 中国“现代书法”论 文选). Beijing: China Fine Arts Press.

GU, G. (1990). The three steps of modern calligraphy. Beijing: China Book Publishing House.

GU, G. (2000). The Art of Gu Gan (Gu Gan shufaji 古干书法集). Beijing: China Cultural Press. 
HU, C. H. (2005). Ambiguous calligraphy—About contemporary calligraphy movements (Aimei de shufa—Guanyu dangxia shufa yundong de jianming baogao 暖昧的书法一关于当下书法运动的简明报告). Art China, 3.

HUANG, R. (Ed.). (2007). Huang Rui: The stars' times, 1979-1984. Beijing: Thinking Hands + Guanyi Contemporary Art Archive.

JIANG, X., \& WANG, D. L. (Eds.). (2005). The act of writing and of non-writing: The open space for Chinese calligraphy. International exhibition of modern calligraphy 2005, Hangzhou, China (Shu feishu—Kaifang de shufa shikong 2005 Zhongguo Hangzhou guoji xiandai shufa yishuzhan zuopinji 书非书一开放的书法时空 2005 中国杭州国际现代书法艺术展作品 集). Hangzhou: China Academy of Art Press.

Kraus, R. C. (1991). Brushes with power: Modern politics and the Chinese art of calligraphy. Berkeley and Los Angeles: University of California Press.

Ledderose, L. (1986). Chinese calligraphy: Its aesthetic dimension and social function. Orientations, 16.

LIU, C. M. (2010). The history of modern Chinese calligraphy (Zhongguo xiandai shufa shi 中国现代书法史). Nanjing: Nanjing University Press.

LIU, C. Y. (2000), Embodying cosmic patterns: Foundation of an art of calligraphy in China. Oriental Art, 5.

LIU, Z. C. (2006). An analysis on contemporary Chinese calligraphy: The new creative models (part I, part II) (Shixi dangdai shufa chuangbian moshi (shang, xia) 试析当代书法创变模式(上、下)). Shufa, 8, 9.

LIU, Z. J. (1999). Painting: A point of view for modern calligraphy. In Y. S. YANG (Ed.), Bashu Parade: '99 Chengdu retrospective of Chinese modern calligraphy at the end of the twentieth century. Chengdu: Sichuan International Cultural Exchange Center.

Pasqualotto, G. (2007). Figures of thought: Works and symbols in the Oriental cultures (Figure di pensiero. Opere e simboli nelle culture d'Oriente). Venezia: Marsilio editori.

PU, L. P., \& GUO, Y. P. (2005). A survey history from contemporary Chinese calligraphy to the art of Chinese characters (Zhongguo xiandai shufa dao hanzi yishu jianshi 中国现代书法到汉字艺术简史). Chengdu: Sichuan Fine Arts Press.

QIAN, Q. G. (2002). My opinion on the new ideas arisen from contemporary Chinese calligraphy (Zhongguo Xiandai Shufa chuanxin zhi wo jian 中国现代书法创新之我见). Shufa yanjiu, 2.

QIU, Z. Z. (1989). The first four series (Guanyu zuichu de si ge xilie ji qita 关于最初的四个系列及其他). Xin meishu, 2.

QIU, Z. Z. (2004). Arising from calligraphy—Naming a new artist category (Yuanzi shufa—Dui yilei yishu de mingming yu qita 源自书法一对一类艺术的命名与其他). In D. L. WANG (Ed.), Florilegium of theses on contemporary Chinese calligraphy (Zhongguo “Xiandaishufa” lunwen xuan 中国“现代书法”论文选). Beijing: China Fine Arts Press.

QU, L. F. (2008). A revaluation of modern Chinese calligraphy in the late 20th century (Chonggu 20 shijimo zhongguo "Xiandai shufa huodong”重估20世纪末中国“现代书法运动” ). Journal of Yibin University, 5.

SHEN, C. Y. F. (1977). Traces of the brush: Studies in Chinese calligraphy. New Haven: Yale University Art Gallery.

Sullivan, M. (1973). The meeting of Eastern and Western art from the sixteenth century to the present day. London: Thames and Hudson.

Sullivan, M. (1980). The three perfections: Chinese painting, poetry and calligraphy. New York: George Braziller.

Sullivan, M. (1996). Art and artists of twentieth century China. Berkeley: University of California Press.

WANG, D. L. (2005). Enjoy the wisdom of modern calligraphy (Xiangshou xiandai shufa de zhihui 享受现代书法的智慧). Art China, 3.

WANG, D. L. (2010). Wang Dongling speaks about contemporary calligraphy (Wang Dongling tan xiandai shufa 王冬龄谈现代 书法). Beijing: Renmin University Press.

WANG, N. M. (1994). Understanding modern calligraphy (Lijie xiandai shufa: Shufa xiang xiandai he qianwei de yishu zhuanxing 理解现代书法: 书法向现代和前卫的艺术转型). Nanjing: Jiangsu Educational Press.

WANG, N. M. (2005). Calligraphic hints in post-abstract art and conceptual art (Hou chouxiang yishu yu guannian yishu zhong de shufa “anshi” 后抽象艺术与观念艺术中的书法“暗示” ). Art China, 3.

WANG, X. Z. (Ed.). (1986). A selection of works from the first session of Chinese Modern Painting and Calligraphy Association (Xiandai shuhua xuehui shufa shoujie zuopin xuan 现代书画学会书法首届作吕选). Beijing: Beijing Sport University Press. 
YANG, Y. S. (2009). The concept of calligraphy: The new contemporary trends (La Calligraphie et le concept: Le nouveaux courants contemporains). In D. A. FAN \& Q. S. ZHU (Eds.), The Orchid Pavilion: The art of writing in China (Le Pavillon des Orchidées: L'art de l'écriture en Chine). Bruxelles: Fonds Mercator.

ZHANG, A. G. (2008). The Blue Book of the Chinese “modern calligraphy” (Zhonguo “Xiandai shufa” lanpinshu 中国“现代书 法” 蓝皮书). Hangzhou: China Academy of Art Press.

ZHANG, N. (1999). A criticism of the complex of modern calligraphy at the end of the century. In Y. S. YANG (Ed.), Bashu parade: '99 Chengdu retrospective of Chinese modern calligraphy at the end of the twentieth century. Chengdu: Sichuan International Cultural Exchange Center.

ZHANG, Q. (2006). “Traceology”-Transcending art (Congjixue-Yishu de wenhua chuanyue 踪迹学一艺术的文化穿越). Chongqing: Chongqing Press.

ZHANG, Q., \& WEI, L. (2012). Biface graphy: From ink painting to abstraction (Shuimo ruhe bei chouxiang: Shuangmian shufa 水墨如何被抽象：双面书法). Chongqing: Chongqing Press.

ZHANG, Y. (2005). Reasons for existence of modern calligraphy (Bushi yizhi ershi kongxin—Guanyu xiandai shufa 不是异质而 是空心一关于现代书法). Art China, 3.

ZHANG, Y. G. (1998). Brushed voices: Calligraphy in contemporary China. New York: Columbia University Press.

ZHENG, L. Y., \& CAO, R. C. (1986). Japanese modern calligraphy (Riben xiandai shufa 日本现代书法). Shanghai: Shanghai Painting and Calligraphy Press.

ZHU, Q. S. (2004). Levels and tendencies of contemporary Chinese calligraphy (Zhongguo xiandai shufa de cengci yu fangxiang 中国现代书法的层次与方向). In D. L. WANG (Ed.), Florilegium of theses on contemporary Chinese calligraphy (Zhongguo “Xiandaishufa” lunwen xuan 中国“现代书法”论文选). Beijing: China Fine Arts Press. 